\title{
Coping with Saltwater: The Condition of Aquatic Insects in Estuaries as Determined by Gut Content Analysis
}

\author{
D. Dudley Williams*
}

\author{
Department of Biological Sciences, University of Toronto at Scarborough, 1265 Military Trail, Scarborough, Ontario, \\ MIC 1A4, Canada
}

\begin{abstract}
The immature stages of freshwater insects can sometimes be found in densities of up to $25,000 \mathrm{~m}^{-2}$ in saltwaterinundated regions of estuaries, however little is known of their condition there. The gut fullness and contents of larvae of two species of hydropsychid caddisfly (Hydropsyche siltalai and H. instabilis) from freshwater and saltwater-inundated sites on the Aber Estuary, Wales were compared in an attempt to assess if the insects were functioning normally, or were in a degraded state after having been displaced downstream by the current. The findings suggest that the downstream larvae were in some ways functioning normally (i.e., attaching to rocks, spinning catch-nets, ingesting locally available food), although the lesser amounts of food contained in their guts (half-full or less) likely indicate that these downstream populations were existing in suboptimal conditions. Further data, for example, on growth rates and success at pupation and adult emergence, will be required to determine if such saltwater inundated populations are truly viable.
\end{abstract}

Keywords: Trichoptera, Hydropsyche, gut analysis, estuaries, salinity tolerance, diatoms.

\section{INTRODUCTION}

Despite being very well established in terrestrial and freshwater environments, insects are poorly represented in marine systems - with the number of species that can be considered to be truly 'marine' numbering only in the hundreds [1]. Most of the latter are associated with coastal habitats, such as saltmarshes, mangrove swamps, decaying seaweeds on strandlines, and estuaries [2-4]. Insects in estuaries have been largely ignored by freshwater- and marine biologists, alike, with relatively few exceptions (e.g., [5-7]).

In a study in New Brunswick, Canada, Williams and Hamm [8] determined that insects formed a significant proportion (17-54\%, by numbers) of the benthic community of coarse-grained-substratum estuaries, and that species richness increased with estuary size. Channel sites inundated by up to $25 \%$ of all incoming tides were dominated by the immature stages of mayflies, stoneflies, caddisflies, elmid beetles, and chironomids, but a gradual loss of species occurred downstream. Nevertheless, even the most seaward sites supported high insect densities (up to 25,016 and 5,433 $\mathrm{m}^{-2}$ ), supporting 26 and 4 species at sites inundated by 75 and $100 \%$ of all incoming tides, respectively. In the Aber Estuary in North Wales, insect densities at comparable sites ranged up to 4,962 and $1,097 \mathrm{~m}^{-2}$, respectively [9]. These insects have been shown to be important in the diet of larval fishes that use estuaries as nursery areas - on a diet largely of chironomid larvae, in the Aber Estuary between March and September, the mean wet weight of flounders (Platichthys flesus) increased by more than 100 times (from 5 to $540 \mathrm{mg}$ ) [10].

\footnotetext{
*Address correspondence to this author at the Department of Biological Sciences, University of Toronto at Scarborough, 1265 Military Trail, Scarborough, Ontario, M1C 1A4, Canada; E-mail: williamsdd@utsc.utoronto.ca
}

In the Aber Estuary, saltwater intrusion is manifest by a wedge of seawater that moves upstream over the surface of the bed on a twice-daily cycle. Benthic insects are thus subject to a repeated and significant change in the osmotic pressure of their environment, although the cycle and degree of change will depend on their location along the estuary. For example, those at downstream Site 5 are typically immersed twice daily by water of 32-34 ppt salinity for periods of 3 to $4 \mathrm{hr}$, whereas those at upstream Site 2 are immersed twice daily by saline water on only approximately 10 days each month, and for only around 0.5 to $1 \mathrm{hr}$ each time. Despite such immersions, high numbers of aquatic insects populate the Aber Estuary bed, comprising 32\% of the total numbers of benthic invertebrates collected in the tidal zone (Sites 2 to 5) [9].

Although numerical and taxonomic data for insects in estuaries are beginning to accumulate, very little is known about the insects' condition and how they cope with increased salinity. The purpose of the present study, therefore, was to try to assess whether the insects found in the lower, and therefore more saline reaches of an estuary were functioning normally, or were in a degraded state after having been displaced downstream by the river current. The approach taken was to analyse the gut contents of two species of hydropsychid caddisfly from the Aber Estuary, comparing gut fullness and composition in larvae collected at upstream and downstream sites.

\section{STUDY SITE}

The Afon Aber $\left(54^{\circ} 14^{\prime} \mathrm{N}, 4^{\circ} 00^{\prime} \mathrm{W}\right)$ arises from the Carneddau mountain range in North Wales and comprises a catchment area of around $24.5 \mathrm{~km}^{2}$. The upper Aber Valley is composed of boulder clay, whereas the valley floor is made up largely of fluvio-glacial sand and gravel. Alluvium is present near the estuary mouth. The estuary is of the 
freshwater-dominated, stratified type, with freshwater flow rates varying annually between about 30 and $110 \mathrm{~cm} \mathrm{~s}^{-1}$. Incoming tides push a visible (semi-opaque) saltwater wedge upstream along the surface of the bed and this creates a layer of saline water that envelops the benthic habitat. Monitoring of salinity levels on both rising and ebb tides showed that very little mixing occurs between the wedge and the overlying fresh water. During the sampling period, at the extreme edge of the wedge front (typically around $5-10 \mathrm{~cm}$ thick) salinity ranges between 8 and 17 ppt. The local tides are semidiurnal, and the maximum annual tidal range is around $10 \mathrm{~m}$. Benthic organisms on the estuary bed are thus subject to inundation by saltwater twice daily.

\section{MATERIALS AND METHODS}

Five sampling stations, each characterised by a different degree of saltwater inundation, were set up along the estuary (Fig. 1). They were: (1) at a point $5 \mathrm{~m}$ upstream of the maximum intrusion of the highest spring tide (extreme high water mark, EHWM, = $10.2 \mathrm{~m}$ ); here the benthic fauna was exposed only to fresh water; (2) at the $9.1 \mathrm{~m}$ mark, here the benthos was inundated by $33.7 \%$ of all high tides; (3) at the $8.4 \mathrm{~m}$ mark which, in this region, represented the level of the mean high water mark (MHWM), here benthos was inundated by $50 \%$ of all high tides; (4) at the $7.6 \mathrm{~m}$ mark, inundated by $80.9 \%$ of all high tides; and (5) at the $6.1 \mathrm{~m}$ mark, inundated by $100 \%$ of all high tides.

Percent of inundation by high tides was calculated by graphing the daily low and high tide heights over the previous year, and choosing a range of values for which corresponding sites along the Aber Estuary could be found. Sites were physically located at the appropriate times of high tide, and marker stakes were driven into the bed. Subsequent inundation measurements made during the study year showed some seasonal variation around the designated sites. For example, taking Site 3 (designated 50\% inundation) as a reference point, $65 \%$ of all high tides inundated this site in April, compared with only $45 \%$ in June.

At Sites 1 to 3, the substratum was typically riverine, comprising cobbles (up to $30 \mathrm{~cm}$ in diameter), stones, coarse and fine gravels, and coarse sand. At Site 4 there was much more sand and gravel with stones, and at Site 5 the substratum was almost entirely sand, but with some small stones. Whereas there was evidence of occasional water-induced bed disturbance at these latter two sites, the substratum at the three uppermost sites remained largely undisturbed over the entire study period.

Caddisfly larvae were sampled between 10:00 and 15:00 hours by hand at the five sites, on a falling tide. This involved two people turning over rocks and gravel in order to look for the larvae and pupae of these insects adhering to the margins and undersides. On each sampling occasion, about 45 minutes were spent collecting caddisflies at each site, beginning downstream - this ensured that at the most inundated sites, larvae were collected soon after retreat of the saltwater wedge. All larvae were thus collected during the freshwater phase of their respective sites. Larvae were initially killed, and their gut contents fixed, by the addition of $20 \%$ formalin solution. After 5 days, they were transferred to $95 \%$ ethanol.

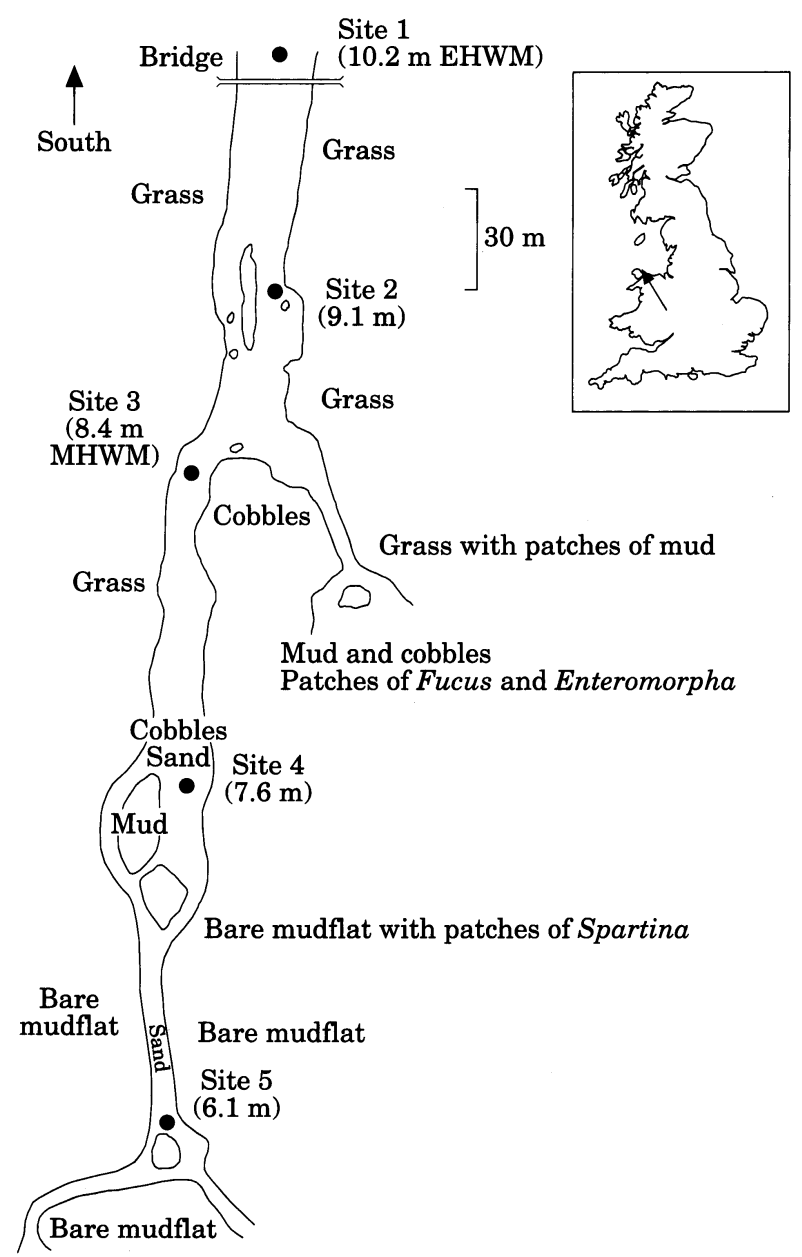

Fig. (1). Map of the Aber Estuary showing features of the bed and channel, together with the 5 sampling sites $(\bullet)$ located at specific tide heights, given in metres (note that Site 1 is above the Extreme High Water Mark, EHWM; MHWM = Mean High Water Mark). Direction of the river flow is from top to bottom.

From the caddisfly larvae collected, the species present at all five sites were identified, counted and measured (maximum headcapsule widths) to establish larval instars. The most abundant proved to be two net-spinning hydropsychids, Hydropsyche siltalai Doehler and H. instabilis Curtis, and as many individuals as possible from the modal size classes present were chosen for gut analysis. Occasionally, specimens from two adjacent sites had to be combined in order to yield sufficient numbers.

The larvae were cleaned of any surface debris, by rinsing in distilled water, prior to dissection. Also, each larva was examined against a bright light under a dissecting microscope (at 10X) in order to assign gut fullness to one of four categories: empty-1/4 full; $1 / 4-1 / 2$ full; $1 / 2-3 / 4$ full; and $3 / 4-$ full. Larvae were then decapitated under distilled water and squeezed along their length until the gut was empty. Detached body parts were removed. After extraction, the gut contents were dispersed by sonication in an ultrasonic cleaner for 30 - 60 seconds before being filtered onto a 0.45 
$\mu \mathrm{m}$ gridded filter (cellulose acetate; Millipore Corporation, Bedford Massachusetts). Filters were cleared on a glass slide for at least $24 \mathrm{hr}$ using Type B non-drying immersion oil (R.P. Cargille Laboratories, Cedar Grove, N.J.). After clearing, a permanent mount was made using Pro-texx mounting medium (Lerner Laboratories, Pittsburgh, PA.). Each slide was then examined under a compound microscope. At magnification $400 \mathrm{X}$, the first 200 particles encountered along one or more randomly selected grid lines (depending on the density of each slide) were counted and classified, according to accepted protocols [11], under one of the following categories:

(a) diatoms - genus and number were recorded;

(b) filamentous algae;

(c) fungal material - hyphae or spores;

(d) vascular plant material - cells distinctly visible;

(e) detritus - amorphous material light brown to black in colour, uniform to granular in texture;

(f) microinorganic particles $-<1.0 \mathrm{~mm}$ in diameter, that were often coated with a thin microfilm of potentially edible material (bacteria, etc.);

(g) marine - anything that might be of marine origin;

(h) chitin and soft body tissues - presumably the remains of prey (although ingestion of pieces of disarticulated chitin with detritus could not be ruled out);

(i) UFM - unidentified filamentous material;

(j) UAM - unidentified animal material;

(k) AFM - attached filamentous material;

Subsequently, the entire slide was scanned, at 100X, in order to estimate the percentages of the total volume of material made up by each category.

\section{RESULTS}

There were no significant differences $(\mathrm{p}>0.2)$ between the mean sizes of the larvae of either H. siltalai or H. instabilis collected at upstream (sites 1 and 2) and downstream (sites 4 and 5) regions of the estuary, and used for gut content analysis: $H$. siltalai mean headcapsule width in December $=1.12 \pm 0.14 \mathrm{~mm}$ (upstream; $\mathrm{n}=10)$ vs $1.34 \pm 0.16 \mathrm{~mm}$ (downstream; $\mathrm{n}=12$ ); H. instabilis mean how in April $=1.19 \pm 0.07 \mathrm{~mm}$ (upstream; $\mathrm{n}=8)$ vs $1.32 \pm 0.05 \mathrm{~mm}$ (downstream; $\mathrm{n}=9$ ).

Comparison of gut fullness at these two locations showed that the majority of $H$. siltalai larvae upstream had guts that were full to $3 / 4$-full (Fig. 2a). In contrast, those found lower down the estuary had guts that ranged from being full to empty, with the majority having guts half-full or less (Fig. 2a). The majority of larvae of $H$. instabilis upstream also had guts that were full to $3 / 4$-full, but the range was full to empty (Fig. 2b). Larvae of $H$. instabilis downstream typically had empty guts, although one had a gut that was $1 / 2$ - 3/4 - full (Fig. 2b).

Mean percent volume of each major food type in the guts of upstream $H$. siltalai, showed that detritus was the most important component, followed by the chitinous remains of prey, microinorganic particles, plant (macrophyte) tissue, and diatoms (Fig. 3a). Lower down the estuary, detritus was again the most important, followed by microinorganics, unidentified filamentous material (UFM), chitin, and plant tissue (Fig. 3b). For upstream larvae of $H$. instabilis, detritus and chitin were most prevalent in the guts, followed by unidentified animal material (UAM), plant tissue, and microinorganics (Fig. 4a). Downstream larvae contained mostly detritus followed by plant tissue, microinorganics, chitin, UFM, and UAM (Fig. 4b). There was no discernable difference in the appearance of the gut detritus among sites.
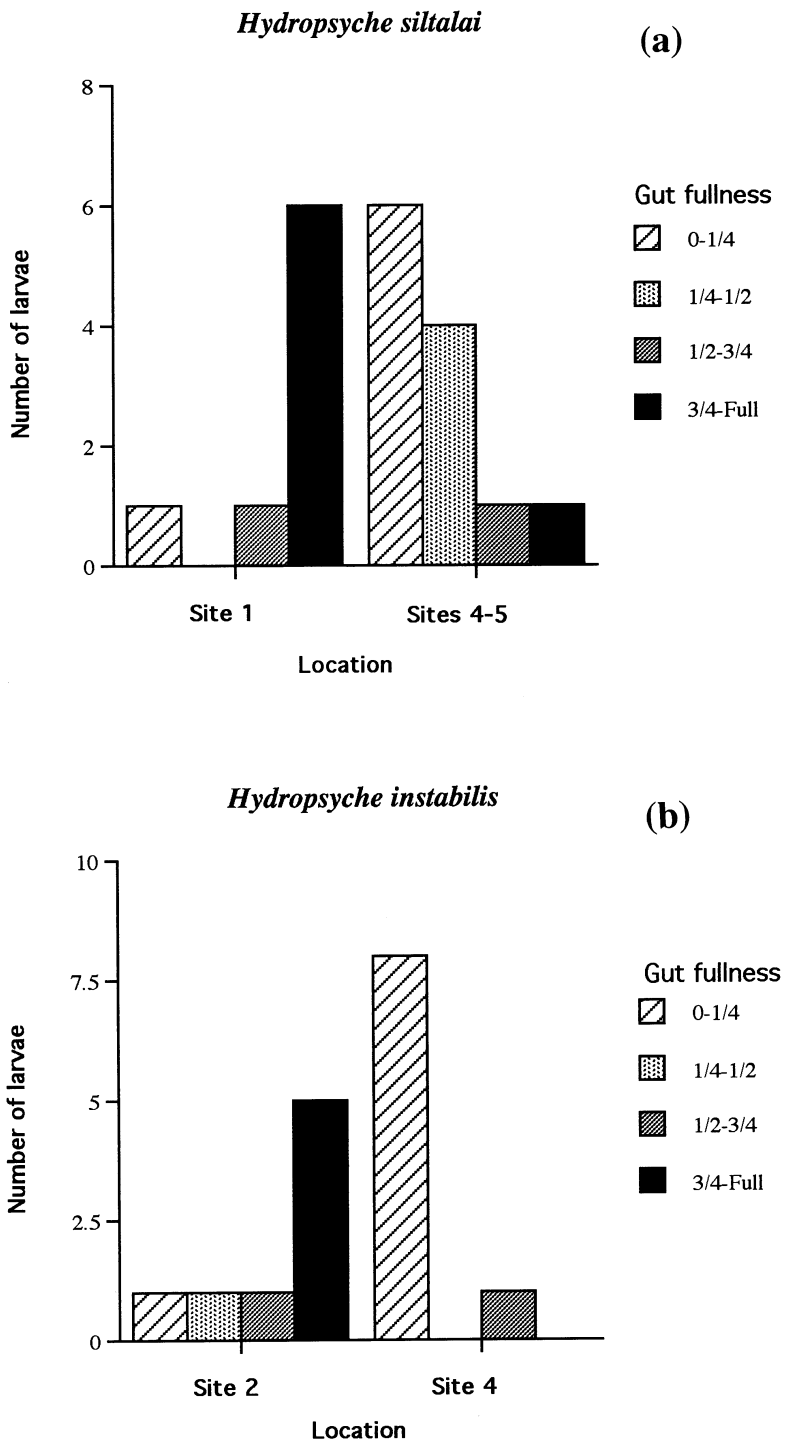

Fig. (2). Comparison of the gut fullness between: (a) similar-sized larvae of Hydropsyche siltalai collected from the Aber Estuary upstream Site 1 and downstream Sites 4 and 5 ( $n=20$ larvae); and (b) similar-sized larvae of Hydropsyche instabilis collected from the Aber Estuary upstream Site 2 and downstream Site 4 ( $n=17$ larvae).

Diatoms were present in all of the guts, and while they did not constitute a major component they were by far the 


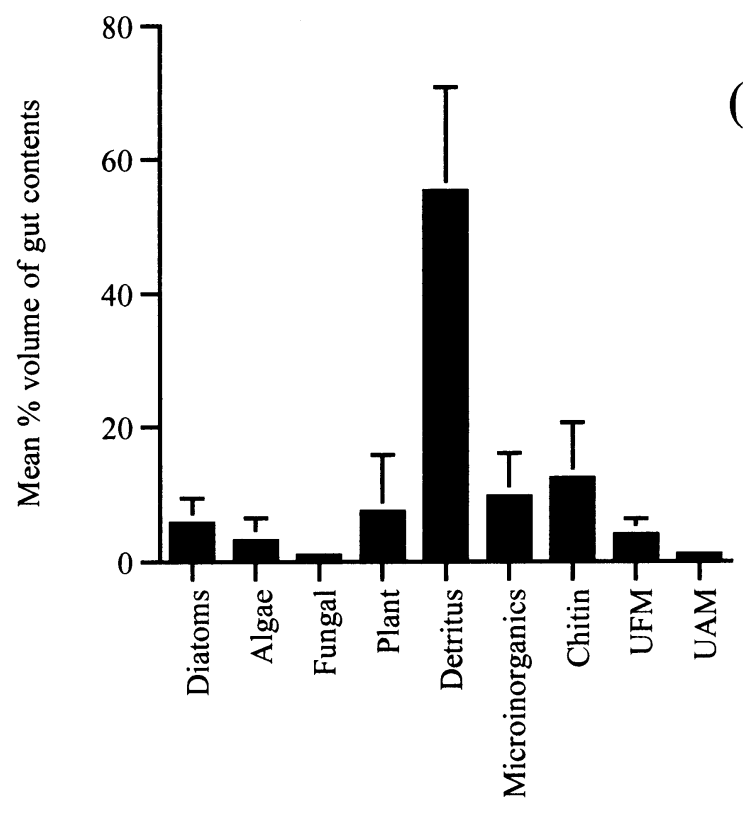

Food type

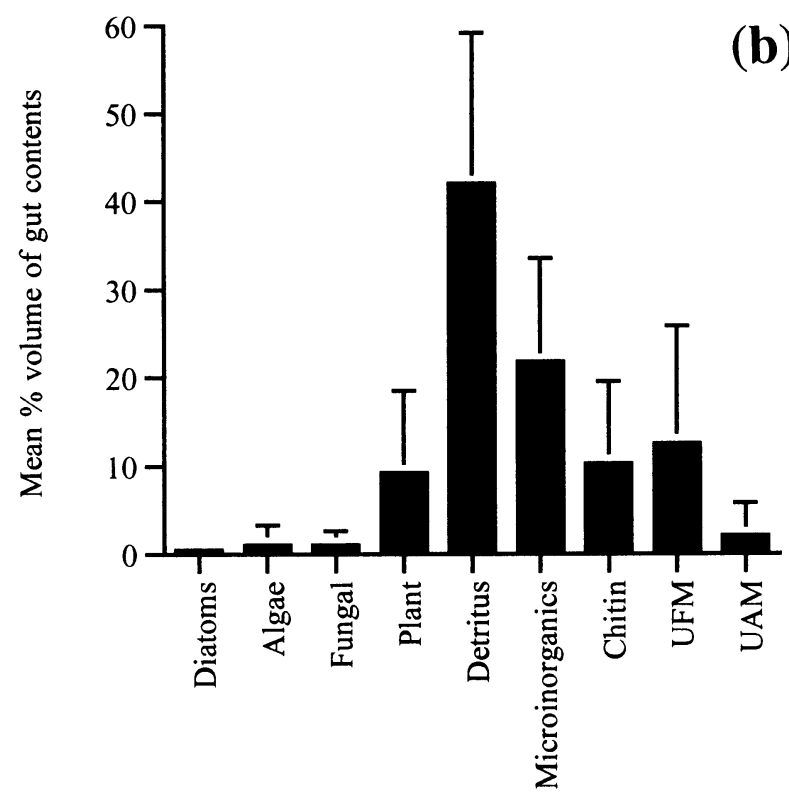

Food type

Fig. (3). Mean $( \pm 1 \mathrm{SD})$ percentage volume of each major food type found in the gut contents of $H$. siltalai collected in December from: (a) the Aber Estuary upstream Site $1(\mathrm{n}=8)$; (b) downstream Sites 4 and 5 , combined $(n=12)$.

best preserved and hence easiest to identify. It was hypothesized that they also might provide clues as to where the larvae may have been feeding, that is in fresh or saline water. Upstream $H$. siltalai gut diatoms were dominated by species of Cocconeis (Fig. 5a), whereas downstream guts contained

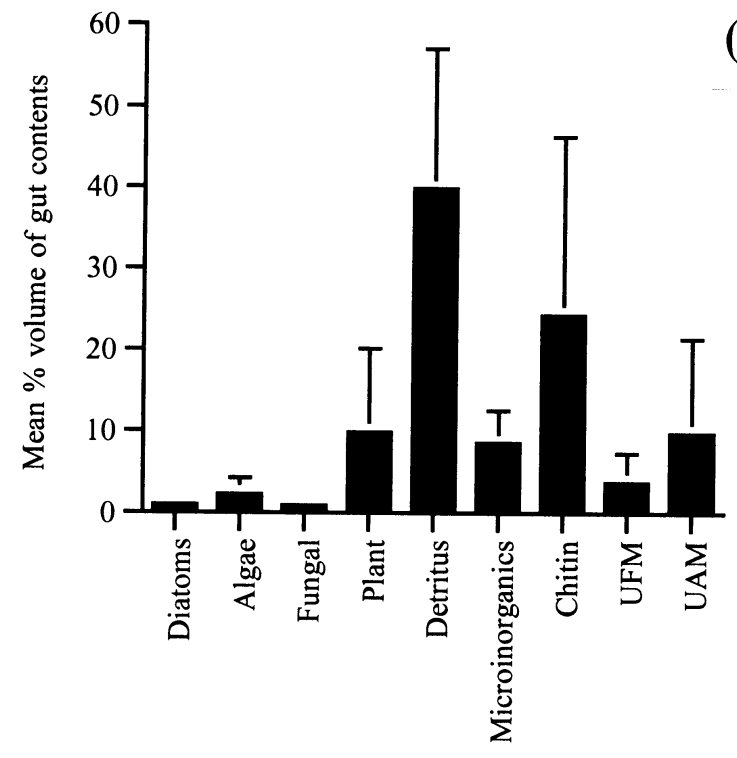

(a)

Food type

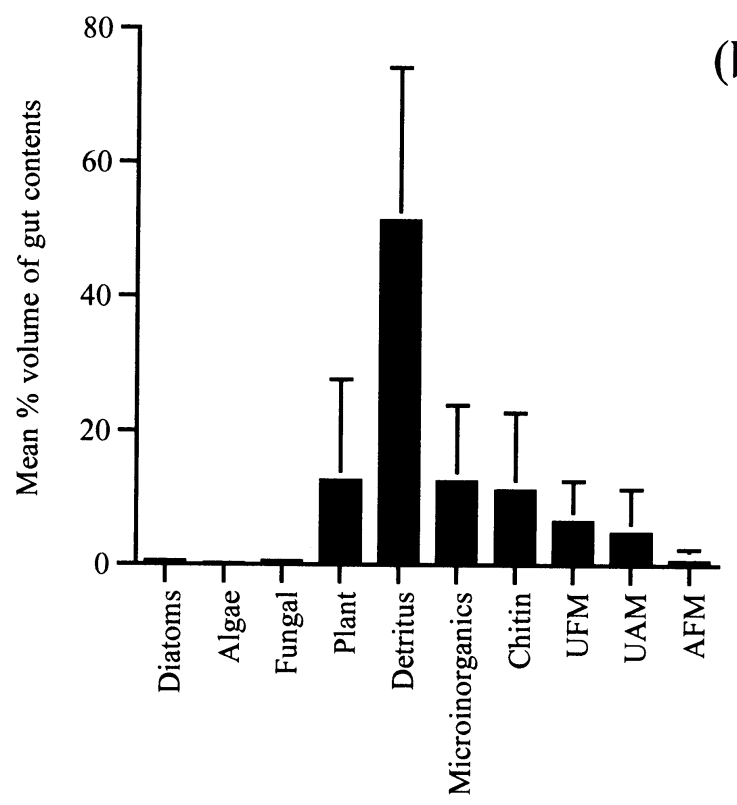

(b)

Food type

Fig. (4). Mean ( $\pm 1 \mathrm{SD})$ percentage volume of each major food type found in the gut contents of $H$. instabilis collected in April from: (a) the Aber Estuary upstream Site $2(n=8)$; (b) downstream Site 4 $(n=9)$.

mostly species of Navicula, but also cells of Planktoniella muriformis, a marine form (Fig. 5b) [12, 13]. This latter marine species was also found in the guts of a number of larvae of Sericostoma personatum (Spence), also collected from the lower Aber Estuary in December. Upstream gut diatoms of 
H. instabilis were dominated by Cocconeis and Navicula (Fig. 6a), and these two genera were also well represented in the downstream guts (Fig. 6b), along with species of Pinnularia, Closterium, Tetracyclus, and Rhoicosphenia - a genus containing fully marine and brackishwater species [14].

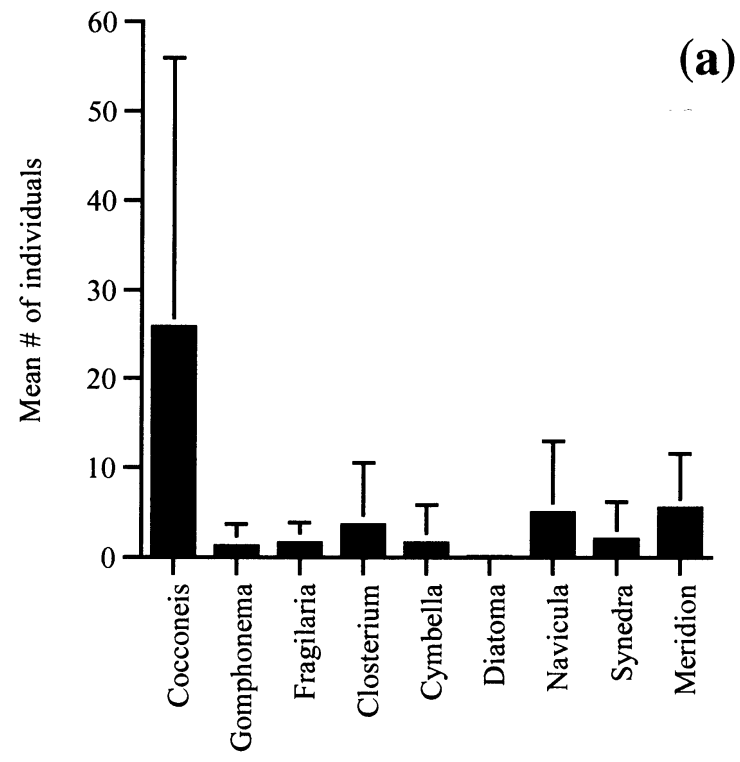

Diatom genus

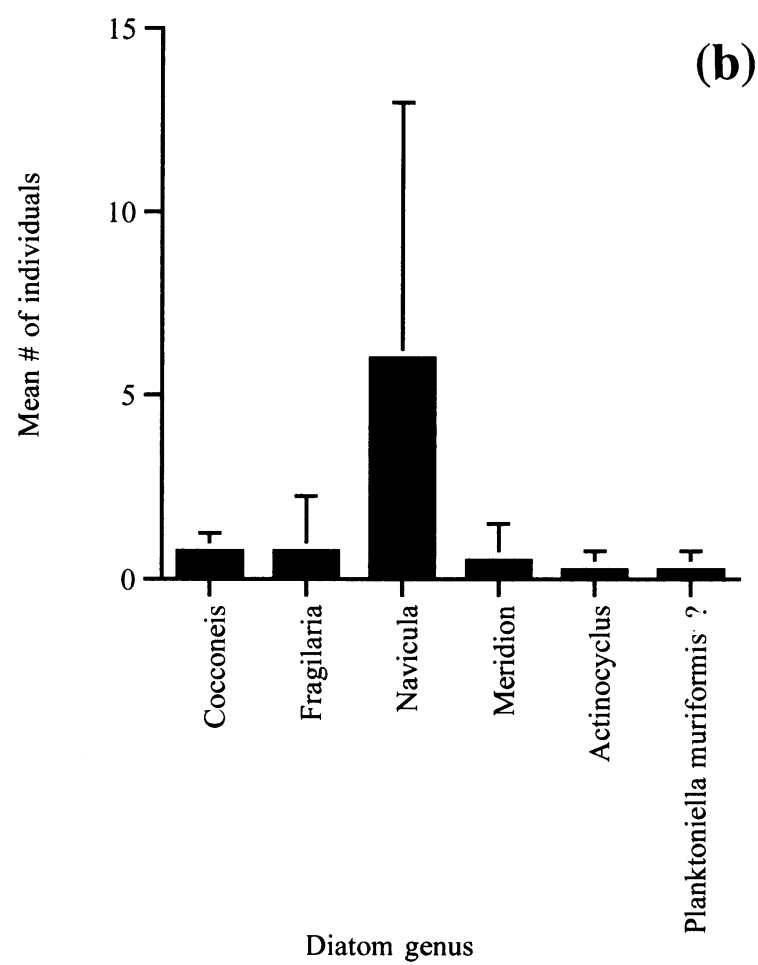

Fig. (5). Mean number of diatoms $( \pm$ 1SD) identified on $0.45 \mu \mathrm{m}$ pore filter papers upon which the gut contents of single $H$. siltalai larvae had been individually trapped: (a) the Aber Estuary upstream Site $1(n=8) ;(b)$ downstream Site $4(n=6)$.

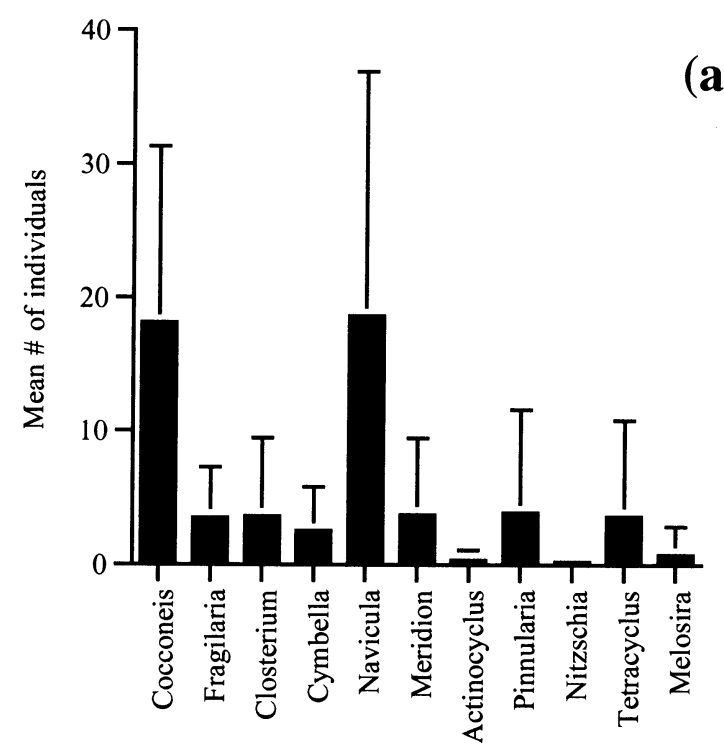

Diatom genus

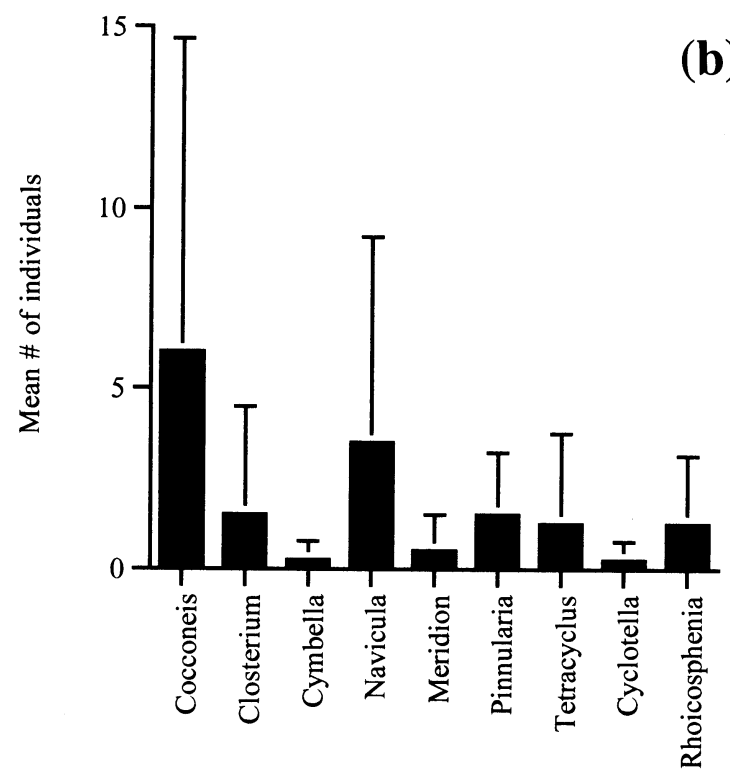

Diatom genus

Fig. (6). Mean number of diatoms $( \pm 1 \mathrm{SD})$ identified on $0.45 \mu \mathrm{m}$ pore filter papers upon which the gut contents of single $H$. instabilis larvae had been individually trapped: (a) the Aber Estuary upstream Site $2(\mathrm{n}=8)$; $(\mathbf{b})$ downstream Site $4(\mathrm{n}=6)$.

The prevalence of species of Cocconeis and Navicula in guts of larvae collected in the upper estuary is likely a reflection of their dominance on rock surfaces at that time. Although algal rock scrapings were not taken, the larval guts of two species of well-known algal scrapers, Glossosoma conformis Neboiss and G. intermedium (Klap.), were analyzed 
as a proxy measure. On average, diatoms comprised $30 \%$, by volume, of the gut contents of $G$. conformis and $20 \%$ of $G$. intermedium (the rest being detritus and microinorganics also swept up from rock surfaces). Further, the predominance of Cocconeis and Navicula (less so in G. intermedium) is clear (Fig. 7a, b). These two species of Glossosoma have poor salinity tolerances [9], and so no proxy measure of the algae occurring on rock surfaces lower in the estuary was available.
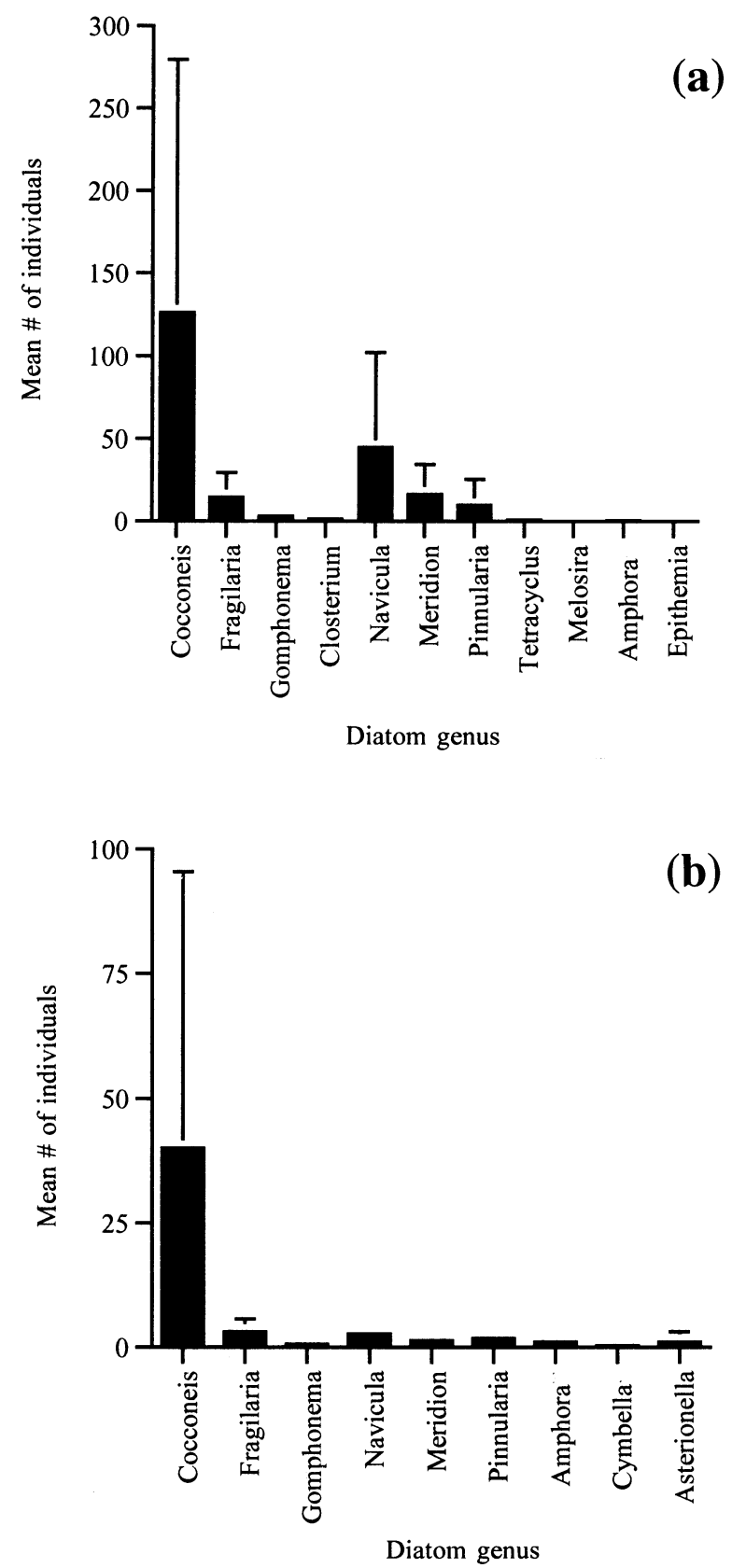

Fig. (7). Mean number of diatoms $( \pm$ 1SD) identified on $0.45 \mu \mathrm{m}$ pore filter papers upon which the gut contents of single larvae of: (a) Glossosoma conformis had been individually trapped (Site 1; $\mathrm{n}=8$ ); (b) $G$. intermedium had been individually trapped (Site 1; $\mathrm{n}=6)$.

\section{DISCUSSION}

The major question addressed in the present study was whether the caddisfly larvae found in the lower, and therefore saltwater inundated, reaches of the Aber Estuary were actually able to live under these conditions, or whether they were existing there in a semi-moribund state after having been displaced from upstream - a previous study showed that up to 123 trichopteran larvae (in a $200 \mathrm{~cm}^{2}$ area of water column) are displaced downstream in the Aber estuary in 24 $\mathrm{hr}$ [11]. Several pieces of evidence suggest that the larvae were not moribund: (1) gut contents; (2) attachment to rocks; and (3) ability to tolerate saltwater.

Clearly, the guts of the two primary study species, $H$. siltalai and $H$. instabilis, collected from the downstream sites more frequently had less food in them than the guts of larvae collected upstream. This could be the result of several factors: possibly the larvae were existing downstream on only the contents of their last meal ingested upstream before they were displaced by the current; alternatively, food resources were less abundant downstream. Diel variation in feeding activity is another possible explanation. However, Tajmrova and Helesic showed no differences in the gut contents of $4^{\text {th }}$ or $5^{\text {th }}$ instars larvae of Hydropsyche saxonica McLachlan 1884 with time of day, or in the gut fullness of $4^{\text {th }}$ instars [15]. The presence of marine-related diatoms in the downstream guts of both species of Hydropsyche, and also in the cased larvae of Sericostoma personatum (Kirby and Spence 1826), suggests that some feeding was taking place downstream. Further, the variety of diatom genera found in the upstream guts of $H$. siltalai and $H$. instabilis was very similar to that seen in the upstream guts of the two algal scrapers, Glossosoma conformis Neboiss 1963 and G. intermedium (Klapalek 1892) (77\% overlap in genera). Similarity of genera in the guts of the upstream glossosomatids compared with the downstream hydropsychids was less (66\%), perhaps indicating that the latter were feeding on a different (downstream) rock-surface community. Similarity of genera in the guts of the upstream versus the downstream hydropsychids was only $57 \%$. Nymphs of the stonefly Acroperla trivacuata (Tillyard 1923) (Gripopterygidae) with food in their guts have been reported from the spring tide level in a small stream at Tauranga Bay, New Zealand (I. McLellan, pers. comm.).

During the process of hand-collecting the hydropsychids from the downstream sites, it was noted that the larvae were lively when disturbed and located in rock-surface positions typical of 'normal' populations - that is, where microcurrent flow was optimal. Indeed, the larvae were attached to the rocks by silk threads, and many had spun what appeared to be functional catch-nets. These are structures unlikely to have been produced by moribund larvae and in hydropsychids have been shown to take up to $3.6 \mathrm{hr}$ to construct $($ mean $=1.3 \mathrm{hr})$ [16]. Interestingly, on occasion larvae were found on the same rocks as another filterfeeder: the barnacle Semibalanus balanoides (Linnaeus) which, because of a tolerance of low salinities, may extend into the lower reaches of estuaries [17].

In a laboratory based study, larvae of both $H$. siltalai and H. instabilis survived imersion in $26.25 \mathrm{ppt}(3 / 4$ strength) seawater for $1 \mathrm{hr}$, and around $20 \%$ of $H$. instabilis larvae survived survived an experiment designed to simulate im- 
mersion according to a $24 \mathrm{hr}$ tidal cycle in the Aber Estuary [9]. Notably, Sericostoma personatum larvae survived well. Larvae were not exposed to increasing salinity levels prior to these experiments, and thus their ability to possibly habituate to estuarine levels was not determined. Nevertheless, a certain ability to tolerate elevated salinity is evident in these caddisfly species.

Although the above evidence suggests that the downstream hydropsychid larvae were in some ways functioning normally (i.e., attaching to rocks, spinning catch-nets, ingesting locally available food), the lesser amounts of food contained in the guts likely indicates that these downstream populations were existing in suboptimal conditions. Further data, for example, on growth rates and success at pupation and adult emergence, will be required to determine if such saltwater inundated populations are truly viable.

\section{ACKNOWLEDGEMENTS}

I thank Marilyn Smith for expert technical help, and Dr. Nancy Logan for caddisfly identification. Dr. Maurice Lock and the School of Biological Sciences, Bangor University provided logistical support.

\section{REFERENCES}

[1] Williams DD, Feltmate BW. Aquatic Insects. C.A.B. International, Wallingford, Oxford 1992; p. 358.

[2] Axtell RC. Horse flies and deer flies (Diptera: Tabanidae). In: Cheng L, Ed. Marine Insects. North Holland Publishers, Amsterdam 1976; pp. 415-46.

[3] Dobson T. Seaweed flies (Diptera: Coleopidae). In: Cheng L, Ed. Marine Insects. North Holland Publishers, Amsterdam 1976; pp. 446-64.
[4] Williams DD. Why are there so few insects in the sea? Trends Entomol 1999; 2: 63-70.

[5] Healey MC. Juvenile Pacific salmon in estuaries: the life support system. In: Kennedy VS, Ed. Estuarine Comparisons. Academic press Inc., London 1982; pp. 315-41.

[6] Mees J, Dewicke A, Hamerlynck O. Seasonal composition and spatial distribution of hyperbenthic communities along estuarine gradients in the Westerschelde. Neth J Aquat Ecol 1993; 27: 35976.

[7] Lafferty KD. Assessing Estuarine Biota in Southern California. USDA Forest Service Gen. Tech. Rep. PSW-GTR-195. 2005; p.15.

[8] Williams DD, Hamm T. Insect community organisation in estuaries: the role of the physical environment. Ecography 2002; $25: 372-$ 84 .

[9] Williams DD, Williams NE. Aquatic insects in an estuarine environment: densities, distribution and salinity tolerance. Freshw Biol 1998; 39: 411-21.

[10] Williams DD, Williams NE. Seasonal variation, export dynamics and consumption of freshwater invertebrates in an estuarine environment. Estuar Coastal Shelf Sci 1998; 46: 393-410.

[11] Tavares-Cromar AF, Williams DD. Dietary overlap and coexistence of chironomid larvae in a detritus-based stream. Hydrobiologia 1997; 354: 67-81.

[12] Round FE, Crawford RM, Mann DG. The diatoms: biology and morphology of the genera. Cambridge University Press 1990; p. 747.

[13] Tomas CR, Ed. Identifying marine diatoms and dinoflagellates. Academic Press, San Diego 1996; p. 598.

[14] VanLandingham SL. Catalogue of the fossil and recent genera and species of diatoms and their synonyms. VI. Rhiocoshenia Through Zygoceros. J Cramer Lehre 1978; p. 635.

[15] Tajmrova L, Helesic J. Circadian changes in feeding activity and diet of Hydropsyche saxonica (Trichoptera). Int Rev Hydrobiol 2007; 92: 539-44.

[16] Boon PJ. Habitat exploitation by larvae of Amphipsyche meridiana (Trichoptera: Hydropsychidae) in a Javanese lake outlet. Freshw Biol 1984; 14: 1-12.

[17] Rainbow PS. An introduction to the biology of British littoral barnacles. Field Stud 1984; 6: 1-51

(C) D. Dudley Williams; Licensee Bentham Open.

This is an open access article licensed under the terms of the Creative Commons Attribution Non-Commercial License (http://creativecommons.org/licenses/by$\mathrm{nc} / 3.0 /$ ) which permits unrestricted, non-commercial use, distribution and reproduction in any medium, provided the work is properly cited. 